\title{
SOME MAJORISATION TYPE DISCRETE INEQUALITIES FOR CONVEX FUNCTIONS
}

\author{
S. S. DRAGOMIR
}

Abstract. Some majorisation type discrete inequalities for convex functions are established. Two applications are also provided.

Mathematics subject classification (2000): 26D15, 26D10.

Key words and phrases: Majorisation type inequalities, Convex functions.

\section{REFERENCES}

[1] A. W. Marshall AND I. Olkin, Inequalities: Theory of Majorisation and its Applications, Academic Press, New York, 1979.

[2] G. H. Hardy, J. E. LitTlewood And G. Pólya, Inequalities, 2nd Ed., Cambridge University Press, England, 1952.

[3] J. KARAMATA, Sur une inégalité relative aux fonctions convexes, Pub. Math. Univ. Belgrade, 7 (1932), $145-148$.

[4] D. S. Mitrinović (IN CO-OPERATION with P. M. Vasić), Analytic Inequalities, Springer Verlag, Berlin and New York, 1970.

[5] L. FuCHS, A new proof of an inequality of Hardy-Littlewood-Pólya, Mat. Tidssker 13 (1947), 53-54.

[6] P. S. Bullen, P. M. Vasić and L. J. Stanković, A problem of A. Oppenheim, Univ. Beograd Publ. Elek. Fak. Ser. Mat. Fiz., 412-460 (1973), 21-30.

[7] J. E. PeČArić, F. Proschan and Y. L. Tong, Convex Functions, Partial Orderings and Statistical Applications, Academic Press, 1992.

[8] E. HewitT And K. Stromberg, Real and Abstract Analysis, Springer-Verlag, 1965.

[9] S. S. DRAGOMIR AND N. M. IONESCU, Some converse of Jensen's inequality and applications, Anal. Num. Theor. Approx., 23 (1994), 71-78.

[10] C. P. NiCULESCU, An extension of Chebychev's inequality and its connections with Jensen's inequality, J. Ineq. \& Appl. 6(4) (2001), 451-462.

[11] S. S. DRAGOMIR, A refinement of Čebyšev's inequality (Romanian), Gaz. Mat., (Bucharest), 8-9(1990), 225-226.

[12] S. S. DRAGOMIR AND J. E. PEČARIĆ, Refinements of some inequalities for isotonic functionals, Anal. Num. Theor. Approx., 18(1989), 61-65.

[13] M. BIERNACKI, Sur une inégalité entre les intégrales due à Tchébyscheff, Ann. Univ. Mariae CurieSklodowska, A4 (1951), 123-129.

[14] H. BuRKILl AND L. Mirsky, Comments on Chebysheff's inequality, Period. Math. Hungar., 6 (1975), $3-16$.

[15] S. S. DRAGOMIR, Majorization type inequalities for integrals and isotonic linear functionals (in preparation). 